\title{
Talent management and high performance work system
}

"Talent management needs to be a strategic issue for organizations"

Professor Chris Bartlett, Harvard Business School

\author{
Beata Maślanka-Wieczorek \\ Polish-Japanese Institute of Information Technology, \\ Warsaw, Poland \\ beata@pjwstk.edu.pl
}

\begin{abstract}
The concept of High Performance Work System - HPWS is a multi-step procedure, requiring the coordination of activities of different organizational functions outside the department of human resource management (HRM) and developing an appropriate strategy for communication between employees. The main pillar in the construction of HPWS is the involvement of employees. The essence of HPWS is to create a system that would make the people employed in the company feel co-owners responsible for its existence and future. As it is commitment that is one of the main ingredients of "talent", the purpose of this article is to attempt to explain what the role of talent management is in the construction of a system of highly effective work. On the basis of the available literature the article presents definitions of "talent", as the management of the potential depends on the understanding of its essence. The paper presents talent management best practice, individual processes of creating a high performance work system and analyzes the determinants of effective talent management. Particular attention was paid to the role of talent in the construction of HPWS.
\end{abstract}

Received: March, 2014 1st Revision: April, 2014

Accepted:

May, 2014

DOI:

$10.14254 / 2071$ $8330.2014 / 7-1 / 9$

Keywords: talent, talent management, systems, High Performance Work System, HPWS

JEL Classification: J53

\section{INTRODUCTION}

Modern organizations operating under global competition and strong pressure on the rapid pace implementing new technologies and developing new products need talents more than ever, meaning employees with high development potential and outstanding professional competence. Increasingly common is the conviction of the necessity of conscious development and directing employees with the highest potential, which is to be a competitive advantage of enterprises. Meanwhile, the high competition induces strong interest in High Performance Work Systems. In turn, the effectiveness of HPWS requires one of the key conditions to be met, namely skillful talent management. To be effective, talent management program is to be compre- 
hensive, i.e. influence talented individuals with a wide range of human capital management tools. Increasing comprehensiveness and the attractiveness of the program contribute to the growth of this type of efficiency, as expressed in the degree of the realization of its objectives. The essence of the analysis of this article is the role that talent management plays in the creation of the high performance work system.

\section{THE DEFINITION OF TALENT}

Currently, both worldwide and in Poland, we can observe an unusual interest in the topic of talent management. Increasingly common is the conviction of the necessity of conscious development and directing the employees with the highest potential, which is to be a factor in competitive advantage. The growing popularity of the concept of talent management enforces precise definition of the concept of talent. In practice, the ability to manage the potential understood in such a way depends on the understanding of its essence. As with other theories and management practices, there is no one, generally accepted definition of "talent". Most definitions assume that talented people have the key skills, abilities, or even a gift, allowing them operate in an extremely efficient way, distinguishing them from other employees. Almost all of the definitions stress uniqueness, limited supply, as a characteristic of talent. It is emphasized that the supply is too small to meet the demand for talented employees arising out of the challenges of the modern economy. Talent should be understood as a person of outstanding potential. According to the most cited and practically applicable Renzulli model, talent consists of the following components (Sękowski, 2004, p.36):

1. Above-average abilities, including: general ability, or increased intellectual potential and specific abilities - within specific fields.

2. Creativity, i.e. originality, novelty, fluency and flexibility of thinking, analyzing new and unconventional problems, openness to ambiguity and uncertainty, risk-taking, sensitivity and rich emotional.

3. Commitment to work, i.e., self-discipline, perseverance in the pursuit of purpose, diligence, endurance, fascination with the work, willingness to sacrifice, faith in their own abilities. These are variables of a social nature, included in charismatic leadership, realized by the leader in their interacting with others. The main skill here is emotional intelligence, in particular: emotional self-control, empathy, the ability to influence, motivate.

Talent is specific to the given company and it is not always possible to be transferred between organizations. For this reason, acquiring talent from other companies, without a careful analysis of its suitability from the organizational point of view, may be inappropriate (Juchowicz, 2014, p.351). Please note that talent is often not a universal concept within a single company. Different features will evidence the possession of talent at various levels of the organization and while acting out different roles. Another issue is to define the egalitarianism or elitism of the concept of talent. In some companies, it is assumed that all of the employees are talented, actions on talent management should be related to all of them. This philosophy of action is well received by employees who appreciate the development opportunities created for them. Often, however, for substantive and financial reasons, such a solution may be only declarative. Talent management is to develop key individuals in the organization, it is a solution that emphasizes the uniqueness of talent, not its universality. For the above reasons, the search for a universal definition of talent may be inefficient for the company. Therefore, the definition should correspond to the specificities and needs of the organization implementing talent management (Kaczmarska, Sienkiewicz, 2005, p.53). 


\section{THE PROCESS OF TALENT MANAGEMENT}

According to Listwan, talent management is a set of actions relating to gifted people, undertaken with the intention of development and efficiency, and achieving the goals of the organization. This whole set of activities can be divided, in accordance with the organizational cycle and recognizing the organization as an open system, into actions associated with entering the organization, transfer and leaving it (Listwan, 2005, p.21). According to Borkowska, talent management will lead to their identification and sourcing in alignment with the organization strategies, their maintenance, motivation to achieve the best possible results and development beneficial to the company and talents (Borkowska, 2005, p.11). In practice, talent management is, therefore, to ensure an appropriate level and the proper flow of talented people within the organization. Management aims to increase the number and availability, and the flexible use of extremely talented (endowed with high potential) employees who may have a significant impact on the effectiveness of the company (Smilansky, 2005, p.18).

P. Brown and A. Hesketh distinguish four main objectives of talent management (2004, p.193). Firstly, the need to build innovation and competitive advantage causes greater importance of recruiting outstanding talents. Their identification, recruitment and retention are the main sources of this advantage. Secondly, there is a limited pool of talents, able to reach senior management positions, which inevitably puts organizations in a situation of fierce competition to recruit the best. Therefore, the key task is to make the company very attractive for talents, for example employer branding ${ }^{1}$. Thirdly, modern recruitment techniques allow to predict the future „stars” (people with the highest results in the future). Fourthly, in order to be able to recruit the best, diversification of talent sources lies in the interest of the organization.

\section{TALENT MANAGEMENT BEST PRACTICE}

Multinational corporations generate multiple solutions recently understood as best practice in the process of talent management. These are mainly: various forms of intensive corporate presence at universities, in order to attract candidates; professional fluctuation analysis at all of the levels of employment, HR performance measures binding efficiency of the HR function with the level of retention; comprehensive development of coaching and mentoring, individualized training programs for employees; programs integrating employees around the acquisition of new skills; development programs for young executives; programs strengthening corporate values and culture (Kwiecień, 2005, p.165).

According to the annual report, "Learning and Talent Development" from 2013, the most effective actions in the area of talent management are: coaching (59\%), which represents an increase of $20 \%$ compared to 2010; internal development programs (38\%) - an increase of $6 \%$ compared to 2010; individual development programs for high-potential individuals (32\%) and 360 degree assessment (28\%) - a decrease of 2\% over the period. In contrast, the main objectives of talent management include: the development of high-potential employees $(67 \%)$, the development of future managers-leaders $(67 \%)$, providing future competence needs of the organization(36\%) and the retention of key people in the company (34\%).

\footnotetext{
Employer branding - targeted and coordinated set of activities in the area of personnel marketing, aimed at building the brand of the organization as an exceptional employer, offering competitive, compared to others', conditions (including financial) of work and opportunity for professional development.
} 


\section{HIGH PERFORMANCE WORK SYSTEM CONCEPT}

Interest in the concept of HPWS began in the U.S. in the early 80 s due to the need to name those configuration, technical, social and managerial aspects of work which can provide high efficiency (Rudolf, 2005, p.108). D.A. Nadler (Woźniakowski, 2005, p.15) started using the name as one of the first authors in 1992. The concept of high performance work system according to Scott Snell is a specific combination of HR practices, work organization and processes that allow for the maximization of workers' knowledge and skills, commitment and flexibility (Snell, Bohlander, 2004, p. 690). As noted by S. Snell, a systemic approach to the set of HR practices is important in that concept rather than focusing on individual practices and emphasis on the achieved measurable results. It is based on a shared pillars, and is an internally matched configuration of policies and practices, selected for achieving high results (Belcourt, Bohlander and Sherman, 2004, p. 166).

It should be noted that HPWS does not belong to the category of systems of action that can be introduced to organizations by organizational rules, since it is a continuous process and not a stable state which, once reached, guarantees long-term successes. It is rather a continuous formation of a work model, which often requires going through a series of developmental stages. One of the tasks is the selection of personnel policy, developing the potential of employees and talent management in accordance with the requirements of the development process. Thus, the organization building the HPWS must answer the question, what employees they need, in order to then identify appropriate methods of selection and development of staff.

According to A. Wypych, in the process of shaping the organization HPWS four stages can be distinguished - from the state typical for most companies, where people just "doing their job" to the full involvement of all of the employees in the implementation of strategic objectives (Wypych, 1999, p.78). Each of these steps requires a slightly different approach to the competence of employees.

STAGE 1: Activity orientation. It is a condition characteristic of most of the organizations in which employees perform their assigned work. In such organizations, the management style is rather directive. Goals are set by top management. There is a clear distinction between "we" - the workers and the "they" - the management, the owners. In a natural way, this may lead to a reduced commitment of employees, and thus create a barrier for increasing the efficiency of the entire organization. According to the ASTD (American Society for Training and Development), 65\% of employees are not engaged enough in the work performed, which could translate into a loss of $\$ 250$ billion (Walker, 2007, p. 57). Of course, on the Polish market, the scale start is correspondingly lower, it can be assumed that the percentage of non-aligned workers is similar. The main task of the organization aiming to introduce the HPWS model is going through to the next stage of development. Thus, competencies improving work are desired: expertise, openness to change, planning skills, teamwork skills, ability to organize own work.

STAGE 2. Skills/competence orientation. This phase of development of the organization in the direction of HPWS is primarily associated with the intensive development of competencies that prepare people for work associated with individually assigned targets (Filipowicz, 2004, p.98). At this stage, goals are already communicated, discussed with teams and become the basis for business planning. The role of direct supervisors change from heads issuing commands to leaders of projects, solving problems. Particular attention is paid to social and managerial skills, such as communication, decision making, problem solving, leadership. System solutions for competence management implemented at this stage of allow to build staff reserves (Smith and Smith, 2005, p.69). 
STAGE 3: Results orientation. In this phase, it becomes important to achieve results expressed in specific, measurable units, as specified for each organizational unit and often people. In this phase, the dominant style of managers changes to "participating". Training programs are more "tailored" and the desirable competencies are: striving for results, creativity, influence. In this phase, management by objectives, coaching and talent management dominate. Therefore, it is essential to create and develop a group of talented people who can work in a flexible manner and among which you can choose successors for vacant positions or assign new roles to them (Armstrong, 2007, p.360). Please note that this is related to the use of internal recruitment -especially for managerial positions (Król, Ludwiczyński, 2006, p. 202).

STAGE 4: High performing work system orientation. Reaching this stage of development can be regarded as the real success of any organization. What distinguishes this stage from the previous one, is the attitude of the staff who operate as if they were co-owners of the company. All of the employees, staff and managers feel responsible for results, not just their own, but the entire company. In such an organization, line employees, working in teams, often deal with multiple functions. They can simultaneously be members of a team responsible for the execution of tasks, members of a project team, managers of other projects and leaders of a team implementing improvements. They make most of the decisions about daily activities and improvements with the help of managers and administrative staff. Employees also determine what support and information they need to work effectively. This requires a very efficient system of information exchange between different places in the organization (Wypych , 1999, p.75). The management model is dominated by a participatory approach. Managers primarily serve the function of leaders inspiring to work and further development. Key competencies needed at this stage are: building an efficient organization, orientation in business process management, strategic thinking. A large access to a variety of development activities, including training, is also characteristic at this stage. It is estimated that $7-8 \%$ of the organization payroll effort is dedicated to training (Ludwiczyński, Filipowicz, 2007, p.81). Another important feature of the organization at this stage are highly developed systems of internal promotion of high-potential individuals, that is talents.

\section{THE ROLE OF TALENTS IN DEVELOPING HIGH PERFORMANCE WORK ENVIRONMENT}

Cascading best practice habits and ways of doing things worked out at one organizational level to lower levels, especially in large organizations, seems to be the key to the success of high performance work environment (Pałamarz 2007, p. 217). The main actors of HRM should actively engage a selected group of high-potential employees in all of the functional areas and business units to work together, to build commitment, but also to develop the resources of knowledge and skills, which others may draw from. To close the process of creating a culture of high efficiency, such a cascade model offers the opportunity to develop talents in a different dimension than the traditional, allows you to learn new practices and ways to manage and allows you to build a network of relations, what is more, with the conviction of contributing the organizational success.

It should be noted, however, that focusing on recruiting talented employees often results in the lack of interest in the already employed people, causing frustration and lack of motivation (Athey, 2004, p.36). In this case, the misunderstood fight for talents can hinder internal learning and knowledge transfer in the organization, creating an attitude of arrogance instead of development orientation (Pfeffer, 2001, p.22). The rational direction of HPWS systems' improvement is the use of such talent management programs that would eliminate the above-mentioned negative effects. The effects should be monitored (e.g., employee 
satisfaction surveys) and minimized through open communication policy and the use of professional development opportunities outside programs.

\section{SUMMARY}

In today's world, success is not based on a carefully structured process of action, but on adaptability, quick decision-making, using intuition and acceptance of risk. The purpose of the article was to show that there is a relationship between HPWS system and effective talent management. As research shows, the most effective methods of the past three years have been: coaching, internal development programs, individual development programs for high-potential people and 360 degree assessment. For the smooth functioning of HPWS, it is necessary to catch and hire talents in the organization, and skillfully manage them. They constitute a potential source of extraordinary effects compared to those provided by mediocre and just good people. It is worth noting that today's companies need to optimize their ability to act flexibly and adapt to new conditions through talents which determine the priority in the construction of the HPWS.

\section{REFERENCES}

Athey, R. (2004), It's 2008: Do You Know Where Your Talent Is? Why Acquisition and Retention Strategies Don't Work, Deloitte Research Study, pp. 28-37.

Armstrong, M. (2007), Zarządzanie zasobami ludzkimi, Oficyna a Wolters Kluwer Business, Kraków, pp. 360-375.

Belcourt, M., Bohlander, G., Sherman, A. (2004), Managin Human Recources, Fourth Canadian Edition, Nelson, pp. 166-180.

Borkowska, S. (2005), Kilka refleksji tytutem wstępu, in: Borkowska, S. (Ed.), Zarządzanie talentami, IPiSS, Warsaw, pp.11-25.

Brown, P., Hesketh, A. (2004), The Mismanagement of Talent. Employability and Jobs in the Knowledge Economy, Oxford University Press, Oxford, pp. 193-210.

Filipowicz, G. (2004), Zarzadzanie kompetencjami zawodowymi, Wydawnictwo PWE, Warsaw, pp. 98-114.

Juchowicz, M. (Ed.) (2014), Zarzadzanie kapitatem ludzkim, PWE, Warsaw, pp. 351-363.

Kaczmarska, A., Sienkiewicz, Ł. (2005), Identyfikacja i pomiar talentu w organizacjach, in: Borkowska S. (Ed.), Zarządzanie talentami, IPiSS, Warsaw, pp. 53-67.

Król, H., Ludwiczyński, A. (Ed.) (2006), Zarządzanie zasobami ludzkimi. Tworzenie kapitatu ludzkiego organizacji, Wyd. Naukowe PWN, Warsaw, pp. 200-227.

Kwiecień, K. (2005), Zarządzanie talentami w międzynarodowych korporacjach, in: Borkowska S. (Ed.), Zarządzanie talentami, IPiSS, Warsaw, pp. 160-175.

Learning and Talent Development (2013), Annual Survey Report, CIPD House, London.

Listwan, T. (2005), Zarządzanie talentami - wyzwanie wspótczesnych organizacji, in: Borkowska S. (Ed.), Zarządzanie talentami, IPiSS, Warsaw, pp. 18-32.

Ludwiczyński, A., Filipowicz, G. (2007), Dobór i rozwój pracowników w procesie budowy HPWS, in: Borkowska S. (Ed.), Systemy wysoce efektywnej pracy, IPISS, Warsaw, pp. 79-89.

Pałamarz, K. (2007), Źródta wysokiej efektywności i metody jej osiagania, in: Borkowska S. (Ed.), Systemy wysoce efektywnej pracy, IPISS, Warsaw, pp. 213-218.

Pfeffer, J. (2001), Fighting War for Talent Is Hazardous to Your Organisations Health, Research paper, No.1687, Graduate School of Business, Stanford University, pp. 18-27. 
Rudolf, S. (2005), Partnerstwo spoteczne a HPWS, in: Borkowska S. (Ed.), Zarządzanie talentami, IPiSS, Warsaw, pp. 106-114.

Sękowski, A. E. (Ed.) (2004), Psychologia zdolności. Wspótczesne kierunki badań, Wydawnictwo Naukowe PWN, Warsaw, pp. 30-43.

Smilansky, J. (2005), The Systematic Management of Executive Talent, Hydrogen, London, pp. 17-26.

Smith, M., Smith, P. (2005), Testing People at Work - Competencies in Psychometric Testing, BPS Blackwell, Oxford, pp. 68-95.

Snell, S., Bohlander, G. (2004), Managing Humań Resources, Thomson South Western, New York, pp. 688-701.

Walker, A. G. (2007), Is Performance Management as Simple as ABC, Training and Development, No. 2, ASTD, Atlanta, USA, pp. 55-67.

Woźniakowski, A. (2005), Koncepcje HPWS. Źródto i rozwój, in: Borkowska S. (Ed.), Zarządzanie talentami, Warsaw, pp. 15-26.

Wypych, A. (1999), Zarzadzanie budowaniem sprawności organizacyjnej na przyktadzie dużej firmy produkcyjnej, niepublikowana praca dyplomowa, Podyplomowe Studium Treningu Kadry Menedżerskiej, Politechnika Gdańska, Gdańsk, pp. 69-93. 